\title{
O contraste de nasalidade em falantes normais e com fissura palatina: aspectos da produção
}

\author{
Camila Queiroz de Moraes Silveira Di Ninno ${ }^{1}$
}

\begin{abstract}
Di Ninno CQMS. O contraste de nasalidade em falantes normais e com fissura palatina: aspectos da produção [tese]. Belo Horizonte: Universidade Federal de Minas Gerais - Faculdade de Letras; 2008.
\end{abstract}

O objetivo deste trabalho foi estudar o contraste da nasalidade de vogais e de consoantes do Português Brasileiro em falantes normais e em falantes com hipernasalidade e investigar a influência da tonicidade silábica e da ênfase neste contraste. Para isso, foram desenvolvidos três estudos, o nasométrico, o aerodinâmico e o de duração, envolvendo a análise de um corpus de oito informantes falantes normais e oito falantes com hipernasalidade decorrente de fissura labiopalatina, todos adultos do sexo masculino, com idades entre 20 e 40 anos. O corpus foi formado por pares de vocábulos com contraste de nasalidade na consoante, em diferentes posições silábicas; e trios de vocábulos, com contraste de nasalidade nas vogais, sendo o primeiro com vogal oral, o segundo com vogal nasal e o terceiro com vogal nasalizada, seguida por consoante nasal. O estudo nasométrico mostrou que falantes normais e falantes com hipernasalidade expressam em sua fala o contraste de nasalidade por meio de valores mais elevados de nasalância para os sons nasais, mas que a magnitude desta diferença é menor para os falantes com hipernasalidade. A posição postônica parece favorecer o contraste de nasalidade, bem como a posição da palavra no final de frase para os falantes normais e na posição medial de frase, quando enfatizado, para falantes com hipernasalidade. $\mathrm{O}$ estudo aerodinâmico revelou que falantes normais expressam em sua fala o contraste de nasalidade por meio de valores maiores de pressão oral e menores de pressão nasal, fluxo nasal e área velofaríngea para a consoante oral bilabial vozeada, quando comparada à consoante nasal bilabial. Falantes com hipernasalidade expressam este contraste apenas com valores mais altos de pressão oral. Para falantes normais a tonicidade não interferiu nos valores aerodinâmicos. A posição tônica inicial e a postônica favorecem o contraste de nasalidade nos falantes com hipernasalidade, por meio do aumento da pressão oral. O estudo da duração indicou que falantes normais e falantes com hipernasalidade expressam em sua fala o contraste de nasalidade por meio de valores de duração mais longos para sons nasais do que para sons orais. Falantes com hipernasalidade apresentam valores mais longos do que falantes normais para sons orais. As posições: tônica inicial e tônica medial parecem favorecer o contraste de nasalidade em relação à duração, bem como a posição medial da frase. A partir dos três estudos realizados, concluímos que falantes com hipernasalidade apresentam a mesma tendência do que falantes normais para expressar na fala o contraste de nasalidade; no entanto, o fazem em uma magnitude menor, o que pode não ser suficiente para ser percebido pelos ouvintes.

Trabalho apresentado à Faculdade de Letras da Universidade Federal de Minas Gerais para obtenção do título de Doutora em Lingüística sob orientação da Profa. Dra. Maria Inês Pegoraro-Krook e co-orientação do Prof. Dr. Cesar Reis.

(1) Doutora, Professora do Curso de Graduação em Fonoaudiologia e do Curso de Especialização em Motricidade Orofacial da Pontifícia Universidade Católica de Minas Gerais - PUC-MG - Belo Horizonte (MG), Brasil; Responsável pelo Serviço de Fonoaudiologia do Centro de Tratamento e Reabilitação de Fissuras Labiopalatais e Deformidades Craniofaciais - CENTRARE - Belo Horizonte (MG), Brasil.

Endereço para correspondência: Camila Queiroz de Moraes Silveira Di Ninno. Av. Dom José Gaspar, 500, prédio 25, Coração Eucarístico, Belo Horizonte-MG, CEP 30535-901. E-mail: camilaninno@uol.com.br 